\title{
Water Management Policy in California: The Status Quo of Command-And-Control
}

\author{
Christina $\mathrm{Oh}$ \\ Communications Manager of Worldwide Public Affairs \\ The Walt Disney Company \\ MA International Studies Aarhus University \\ Denmark \\ E-mail: oh.christina@gmail.com \\ Gert Tinggaard Svendsen \\ Dept. of Political Science \\ Aarhus University \\ Bartholins Allé 7 \\ DK-8000 Aarhus C \\ Denmark \\ E-mail: gts@ps.au.dk
}

Received: October 6, 2015 Accepted: November 4, 2015 Published: November 25, 2015

doi:10.5296/ijrd.v2i2.8405 URL: http://dx.doi.org/10.5296/ijrd.v2i2.8405

"And it never failed that during the dry years the people forgot about the rich years, and during the wet years they lost all memory of the dry years. It was always that way." - John Steinbeck, East of Eden

\begin{abstract}
Using Olson's 1965 logic of collective action and group theory, we argue that the "small group" of the "iron triangle" is able to collectively act to push for command-and-control regulations in Californian water policy. There are individual rent-seeking incentives in the small group because the politicians do not want to impose tax, and they would like to have short-term development and economic growth during their term in order to gain a positive reputation from the public or to get re-elected. The developers would like more work and prestige and the water bureaucrats have little incentive to limit development and alienate
\end{abstract}


politicians. However, by focusing on command-and-control (CAC), the citizens may end up paying more to fund these projects. CAC is easier to hide than environmental taxes which are more explicitly shown to citizens. Thus, the ignorant majority is exploited by the knowledgeable minority. Thus, the small group of the iron triangle defends the status quo at the expense of the citizens and the public interest at large.

Keywords: US, California, water management policy, command-and-control (CAC), iron triangle, rent-seeking.

\section{Introduction}

California has a long-standing history of water politics and conflicts over water. The size of the state, the number of people, and the complexity of the hydrology of the state have led to an "expensive, sophisticated and controversial water system to address the needs of competing interests and stakeholders" (Gleick et al., 2003, p. 22). Water is viewed as an extremely precious commodity. Article 10, Section 2 of the California Constitution requires that the "water resources of the State be put to beneficial use to the fullest extent of which they are capable" and prohibits the waste and unreasonable use of water (CDW, 2009).

To achieve this goal, Californian policy-makers have so far used command-and-control (CAC) regulations as the leading instrument in governing the state's water consumption. The state of California lies on the west coast of the United States and has a population of approximately 36.9 million people (CDW, 2009). The state continues to experience significant population growth, dominated by resident birth rates and also contributed to by immigration. To meet water needs, California water supply heavily relies on the accumulation of winter, mountain snow melting in to spring and summer runoff. Much of the state's water supply is stored in an extensive system of reservoirs and aqueducts. Water stress is already high in California, and water utilities will be subjected to increasing demand due to the increasing population and climate change (Tietenberg, 2007, p. 174).

Many state agencies are involved with water management. The State Water Resources Control Board (SWRCB) and California Department of Water (CDW) are California's two leading water management agencies. The CDW focuses on water delivery, water supply planning, and infrastructure development whereas SWRCB is more of a regulatory body that manages water rights and water quality permitting (CDW, 2009). The management of California's water system consists of three key components: water supply, water quality, and flood control. On a federal level, most agencies have very distinct roles. For example, the U.S. Environmental Protection Agency (EPA) focuses on water quality while the U.S. Bureau of Reclamation focuses on water supply. On a local level, there are over 1,200 water districts in California that provide water delivery, sanitation and/or flood control (CDW, 2009).

Precipitation in California varies widely each year (CDW, 2009, p. 2). California has experienced several multi-year periods of wet or dry cycles in the past 100 years. There have been several drought periods including the recent drought in year 2009. The CDW explains that although the drought in 2009 is comparable to the great drought in 1977, California has dramatically changed. California's population is $75 \%$ higher and there is a considerably 
reduced water supply. The year 2009 was the third consecutive year with below average precipitation for the state. Water years 2007 and 2008 were respectively 63 and $76 \%$ of average annual precipitation (CDW, 2009, p. 8). This water shortage has affected the state's economy as it has slowed development projects and forced farmers to fallow land. Per capita water use among urban users varies substantially between inland and coastal areas of the state. In general, urban per capita water use has been slowly declining overall in California, with coastal areas generally following this trend. However, inland areas where hotter climates tend to occur have increased per capita water use in recent years.

In 2008, California Governor Schwarzenegger called for "a plan to achieve 20 percent reduction in per capita water use statewide by 2020" (CDW, 2009, p. 9). In order to develop this plan, CDW created a "20x2020 Team" of state agencies who eventually drafted the 20x2020 Water Conservation Plan. Senate Bill x7 7 Water Conservation Plan of 2009 put this draft into action and sets forth a statewide road map to maximize the state's urban water efficiency and opportunities between 2009 and 2020 and beyond (CDW, 2010, p. 11). It requires the state of California to achieve a $20 \%$ reduction in urban per capita water use by 31 December 2020 (CDW, 2009, p. 10). This law requires incremental progress towards this goal by stating that there must be at least a $10 \%$ reduction by 31 December 2015 . Each urban retain water supplier must develop urban water use targets in accordance with these requirements.

By putting this 20x2020 goal into legislation, California emphasized the importance of water efficiency. However, although there is a clear goal, there have not been many concrete changes in other water policies to meet this goal. Effective strategies such as reinforcing efficiency codes and providing financial incentives were recommended by some political decision-makers, but these were mere recommendations (CDW, 2009, p. 9). The 20x2020 goal seems very ambitious without much substantial or concrete action being taken to meet it. It is a CAC regulation that instructs water suppliers and consumers to decrease water consumption, but offers minimal or no tools to fulfill the target.

Traditional CAC regulation still prevails within water resource management in California in spite of the fact that market instruments are gaining territory. Until recently, environmental regulators saw the market as a "power adversary" and market forces as forces that acted to degrade the environment. However, this attitude has changed as the "adversary" has turned into a "powerful ally" (Tietenberg, 1990, p. 17). Market-based regulations were seen as providing flexibility and as a way for individuals to select the best means of meeting an environmental goal (European Environment Agency, 2006; Goulder \& Parry, 2008). As argued by $\mathrm{Oh}$ and Svendsen (2015), Denmark is one rare example where economic instruments such as taxation have been used.

Still, the non-economic instrument of CAC policies prevails as is the case in Californian water resource management. This top-down approach gives the people subjected to regulation very few incentives to voluntarily improve their performance (Andersen, 1994a, p. 5). For example, the government could simply specify the requirements and make it an offense to fail to comply with these. 
The article takes a departure from the idea that environmental problems can be traced back to policy failure. Policy failures arise from "government policies that generate perverse incentives with regard to resource use and environmental pollution" (Speck et al., 2006, p. 18). Failed policies encourage over-exploitation of resources and/or generate excessive amounts of waste. They can be in the form of environmentally damaging subsidies which are put in place "to enhance the competitiveness of certain products, processes, economic sectors or regions" and end up "discriminating against sound environmental practices" (ibid.). For example, this is shown in inefficient water resource management.

Thus, this article seeks an answer to the empirical puzzle of why political decision-makers in California maintain the status quo of CAC when market instruments are more efficient from the perspective of overall society. This is done by simple theoretical outlining where the principle of Ochams' razor is truly used: any inessential premises or complexities ought to be cut out of an argument to simplify the extremely complex reality of environmental regulation (Daugbjerg \& Svendsen, 2003). Our research method is the case study and the use of mainly qualitative data, such as interviews or written statements. Thus it is possible to investigate motivations and perceptions behind political behavior, such as the incentives for fighting political reforms within water regulation. More specifically, we compare an empirically based pattern in the case of water management policy in California to the theoretically predicted one. If patterns coincide, the theory is confirmed and an explanation is provided (Svendsen \& Svendsen, 2014).

First, Section 2 demonstrates why CAC is an inefficient approach to water resource management in terms of the public interest. Next, Section 3 explains, why small-sized interest groups may have a private interest in fighting policy reform and maintain the status quo. Section 4 gives the conclusion.

\section{Theory on CAC}

The traditional way of controlling pollution in Western Europe has been regulation by the use of CAC (Daugbjerg \& Svendsen, 2001). It tends "to force all businesses to adopt the same measures and practices of pollution control and thus accept identical shares of the pollution control burden regardless of their relative impacts" (Andersen, 1994a, p. 21). Thus, CAC regulations set standards, monitor and enforce. They are traditionally the most common way for policy-makers to regulate the environment. The government simply specifies what is required, and, subsequently, it becomes an offence to fail to comply with this requirement (Hodge, 1995, p. 88). CAC regulations can take various forms. It can be an environmental quality standard that must be achieved (e.g. the concentration of a particular chemical in a body of water), a specific amount of emissions that are permitted (e.g. noise level from an airport), or a particular action that must or must not be taken (e.g. a ban on a certain chemical) (ibid.).

Regulations are generally easy to introduce and to administer. However, to make CAC regulations cost-effective, the "amount of information needed required by the regulatory authority is substantial" since the regulators "need to work out for themselves details of the way in which and to the extent to which individual firms should act" (ibid., p. 89). 
Governments rarely have that type of detailed information, thus forcing regulators to introduce regulations without this information. Consequently, the costs are usually not minimized. For this reason, many economists generally advocate the use of market-based instruments such as taxes rather than CAC. Figure 1 illustrates why.

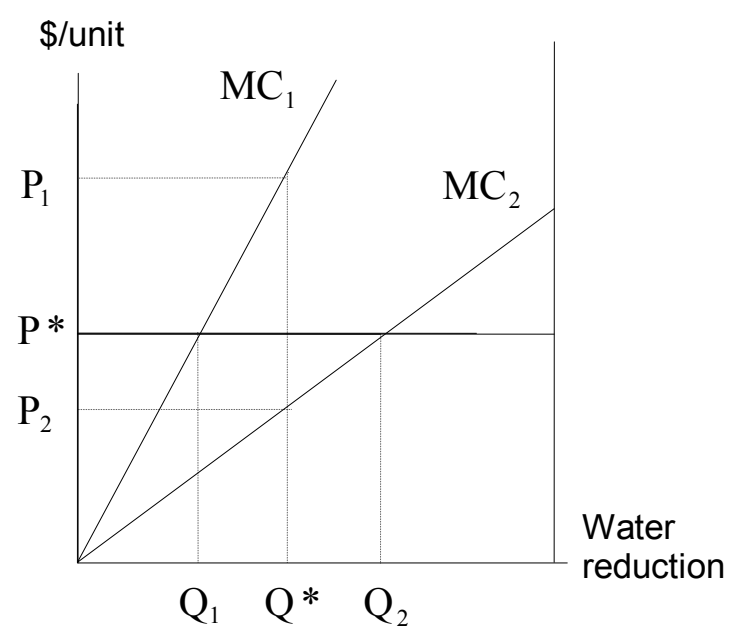

Figure 1. CAC and taxation

Assume that two farms exist as represented by the marginal cost curves $\mathrm{MC}_{1}$ and $\mathrm{MC}_{2}$ respectively. If it is politically decided that the use of water should be fixed at the level of $\mathrm{Q}^{*}$, then the environmental authorities may use CAC or a tax to achieve this goal. CAC means that both farms in total must respect $\mathrm{Q}^{*}$. Note that the marginal cost of farm $2\left(\mathrm{MC}_{2}\right)$ is less than the marginal cost of firm $1\left(\mathrm{MC}_{1}\right)$ at the existing level of production. Thus, it would be better for the economy as a whole to require farm 2 to provide water reduction up to $\mathrm{Q}_{2}$ whereas farm 1 should provide $\mathrm{Q}_{1}$ water reduction only. Thus, by alternatively using a tax $\mathrm{P}$ *, firm 2 and firm 1 will get the right economic incentives and together achieve $Q^{*}$ in a cost-effective way (see Baumol \& Oates, 1988; Daugbjerg \& Svendsen, 2001).

In spite of less cost-effectiveness, Stavins (2003) explains that CAC instruments have predominated because all of the main parties involved have reasons to favor them: affected firms, environmental advocacy groups, organized labor, legislators, and bureaucrats. Traditionally, legislators have found CAC regulations attractive. First, many legislators are trained in law, which may predispose them to favor legalistic approaches (ibid: pp. 12-13). Second, standards tend to help hide the costs while taxes generally impose these costs more directly and explicitly. The benefits of market mechanisms are often "invisible to consumers, while the costs they impose as fees or taxes are all too plain" (Stavins \& Whitehead, 1997, p. 111).

Stavins (2003) gives the example that the nature and tone of public debate would greatly differ from a discussion on a proposal for increases in gasoline taxes from a discussion on 
commensurate increases in the stringency of fuel economy standards for automobiles (ibid: 14). Additionally, standards offer greater opportunities for symbolic politics as strict standards symbolize strong statements of support for environmental protection, even if enforcement measures are not as strict later on. Lastly, bureaucrats are more wary of taxes and legislators are cautious of enacting programs that are likely to be undermined in their implementation by these bureaucrats. Taxes can imply a "scaled down role for the agency by shifting decision-making from the bureaucracy to the private sector," and thus bureaucrats may oppose taxes to "prevent their expertise from becoming obsolete" (ibid.). Taxes can offer many advantages over CAC regulations; operational simplicity for example. If properly implemented, taxes can reduce administrative costs compared to CAC.

\section{Logic of Collective Action and the "Iron Triangle"}

In his famous 1965 book, The Logic of Collective Action: Public Goods and the Theory of Groups, Mancur Olson writes about how groups are formed and investigates economic incentives and disincentives for group formation and collective action. He questions accepted wisdom about "group theory", a theory that claims that groups will act to further their common group goals. He challenges the idea that "groups of individuals with common interests are expected to act on behalf of their common interests much as single individuals are often expected to act on behalf of their personal interests" (Olson, 1965, p. 1). The "group theory" argument arose from the idea that rational individuals act in a self-interested way, and that, in the same manner, individuals in a group will act in the same rational, self-interested way as a group. However, Olson refutes this assumption and emphasizes that individuals will "not voluntarily act to achieve that common or group interest," and he argues against the logic that "groups act in their self-interest" because individuals do (ibid, p. 2).

The central thesis in Olson's book is that larger groups are less likely to achieve their goals than smaller groups. He argues that this is so because individuals in a group do not have incentives to act, because the larger the group, the smaller the benefit of any one individual. In large groups, each person gets a proportionally smaller benefit of the collective good. Since the individual gets a small portion of the benefit, the individual will only contribute to the group to a limited extent. Thus, one individual member of a group will rarely act to secure the collective good of the group, unless that individual's return will cover the individual's expenses or costs of acting. In addition, the organization of a large group is more costly than the organization of a small group. Small groups are therefore more capable of reaching their goals, because the costs of organization are less and each individual member of the group receives a more substantial portion of the collective good (Olson, 1965, p. 63). The collective good is provided by the voluntary and rational action of the members who find that the benefit of providing the good exceeds the costs they bear in this action. Of course, some small group members may free-ride off of the members who do provide the good, as the former see no incentive to provide the good and thus end up exploiting the few members who do act. Olson also emphasizes that small groups will never operate perfectly, since the distribution of goods and burdens among members will always be unequal. 
Olson's logic basically shows the problem of free-riding. Group benefits are inherently shared so individuals cannot privatize their own benefit. In large groups, each group member has a lower share of the benefit, and therefore it is less likely that any one member's benefits of helping provide the good will exceed the costs. Larger groups are more likely to have free-rider problems, and members of a large group have less incentive to act. He compares this to meetings that "involve too many people" and "accordingly cannot make decisions promptly or carefully" (Olson, 1965, p. 53). When there is a large number of participants, a typical individual participant knows that "his own efforts will probably not make much difference to the outcome," and, thus, this participant will not make as much effort to understand the issues in question (ibid.).

The greater effectiveness of small groups is shown in Olson's logic of collective action and group theory same and he quotes George Simmel, who states that "smaller groups could act more decisively and use their resources more effectively than large groups" (Olson, 1965, p. 54). Small groups are better at overcoming the collective action problem and undertake rent-seeking that affects the choice of status quo or policy change in favor of their special interests (Brandt \& Svendsen, 2016).

Hillman (2009: 85) defines a rent as: “...a personal benefit that would not be obtained in a competitive market." Thus, a rent is a politically created special benefit outside the market and: "Public policies also confer rents-for example, through lax environmental regulation" (ibid.) Hillman continues: "Rent-seekers do not ask, "How can I productively earn income today?" Rather, they ask themselves, "How can I convince someone to do something for me today?" (ibid.) As such, rent-seeking may explain why the economists' strong theoretical rejection of the use of command-and-control has not been applied in practice.

Concerning the case of Californian water policy-making, Zetland identifies four sets of rent-seeking actors: water bureaucrats, politicians, developers, and citizens (Zetland, 2009, p. 350). Consequently, in the line of Olson (1965), the "small group" consists of the bureaucrats, politicians, and developers (what Zetland calls the "iron triangle") whereas the citizens become the "large group." Thus, the three actors, the bureaucrats, politicians and developers, can easily form the "small group" of the "iron triangle" that would "support growth inconsistent with maximized social welfare" because they would "enjoy the benefits of growth while leaving the costs to fall on citizens" (Zetland, 2009, p. 351). These actors in the "small group" have more to gain from CAC regulations that continues to rely on supply-side management in California.

The bureaucrat has little incentive to limit development and alienate politicians. The politicians do not want to enact politically unpopular policies and want growth during their term. Therefore, they would rather build a dam than increase taxation on water. The water developers want more work and prestige, and hence, they will always favor expansion on the supply-side of water. The "iron triangle" therefore pushes for expansion funded by taxpayers. This "iron triangle" can, for example, promote a large-scale desalination project rather than finding ways to decrease consumption. This "exploitation of the 'ignorant' majority by the 'knowledgeable' minority" helps to explain why the water sector in California chooses the 
policies they do. It shows why these actors do not choose to use the more effective tool, taxation, in their policy-making.

CAC instruments can also be "comforting to politicians and people: governments know what they are asking for, people know what they are getting, companies know what they are supposed to deliver; the only people who do not like it are economists" (The Economist 1989 in Andersen 1994b: 1). CAC standards are often preferred by legislators (i.e. this "small group") since they may be more comfortable with a direct standards approach, rather than market-based approaches. Standards also tend to hide the costs of control while emphasizing the benefits, and standards offer greater opportunities for symbolic politics (Stavins \& Whitehead, 1997, p. 110). Politicians are able to hide the full costs and their distribution in regulation, thus avoiding public debate and controversy on equity. In consequence, the "small group" in California may also rely on CAC instruments due to comfort issues and rent-seeking.

\section{Conclusion}

California faces water scarcity issues but has chosen an inadequate CAC approach. The overall research question therefore addressed the empirical puzzle of why California has chosen to maintain the status quo rather than implement the needed policy reforms. Based on Olson (1965), we hypothesized that the small-sized groups were in a strong position to maintain the status quo of CAC at the expense of the large group of citizens.

The "small groups" of politicians, developers and bureaucrats formed an "iron triangle" (Zetland, 2009) and, in this way, established a coalition that was able to collectively push for CAC regulations in their water policy. There were individual rent-seeking incentives in the small group as the politicians did not want to impose market-based instruments. Rather, they would like to have short-term development and economic growth during their term in order to gain a positive reputation from the public to get re-elected. The developers would like more work and prestige and the water bureaucrats have little incentive to limit development and alienate politicians. By focusing on CAC and supply-side management, however, the voters may end up paying more to fund these projects. CAC is easier to hide compared to environmental taxes that are more explicitly shown to citizens. The ignorant majority is exploited by the knowledgeable minority. Thus, the "small group" continues to "defend a status quo management strategy that serves their interests but not those of citizens" (Zetland, 2009, p. 350).

Overall, Olson's "small" and "large" group theory helps to explain why rent-seeking policy-makers in California pursue CAC rather than market-based instruments. Because of a lack of political feasibility to install market-based instruments, Californian politicians often resort to CAC regulations which seem to be less wasteful to the citizen at the time. The costs are much more hidden in CAC regulations than in a market-based instrument solution such as taxation. Additionally, group theory shows how the "small group" (the political decision-makers) can successfully join together and lobby for their own interests. In this case, the "small group" in California has very little incentive to deviate from CAC instruments as 
they can enjoy their private success of these instruments at the expense of the citizens and the public interest.

Future research should try to investigate how general this result is. Can the same theory explain other cases in for example the United States or Europe? Could other rival theories be reinforced or is it even possible to develop new theoretical propositions and explanations.

\section{References}

Andersen, M. S. (1994a). Governance by green taxes: Making pollution prevention pay. Manchester: Manchester University Press.

Andersen, M. S. (1994b). The use of economic instruments for environmental policy: A half-hearted affair. Aarhus: Department of Political Science, Aarhus University.

Baumol, W. J., \& Oates, W. E. (1988). The Theory of Environmental Policy (2nd ed.). Cambridge: Cambridge University Press. http://dx.doi.org/10.1017/CBO9781139173513

Brandt, U. S., \& Svendsen, G. T. (2016). The Politics of Persuasion: Should Lobbying be Regulated in the EU? Cheltenham, UK: Edward Elgar Publishing.

CDW. (2009). California Water Plan: Update 2009, California Department of Water, Sacramento.

CDW. (2010). 20x2020 Water Conservation Plan. California Department of Water, Sacramento.

Daugbjerg, C., \& Svendsen, G. T. (2001). Green taxation in question: Politics and economic efficiency in environmental regulation. Basingstoke: Palgrave. http://dx.doi.org/10.1057/9780230595538

Daugbjerg, C., \& Svendsen, G. T. (2003). Designing green taxes in a political context: From optimal to feasible environmental regulation. Environmental Politics, 12(4), 76-95. http://dx.doi.org/10.1057/9780230595538

European Environment Agency. (2006). Using the market for cost-effective environmental policy: Market-based instruments in Europe. European Environment Agency.

Gleick, P., Haasz, D., Henges-Jeck, C., Srinivasan, V., Wolff, G., Cushing, K., \& Mann, A. (2003). Waste Not, Want Not: The Potential for Urban Water Conservation in California. Berkeley: Pacific Institute for Studies in Development, Environment, and Security.

Goulder, L. H., \& Parry, I. W. H. (2008). Instrument choice in environmental policy. Review of Environmental Economics and Policy, 2(2), 152-174. http://dx.doi.org/10.1093/reep/ren005

Hillman, A. L. (2009). Public Finance and Public Policy. Responsibilities and Limitations of Government. Cambridge: Cambridge University Press. http://dx.doi.org/10.1017/CBO9780511813788 


\section{Macrothink}

International Journal of Regional Development ISSN 2373-9851 2015, Vol. 2, No. 2

Hodge, I. (1995). Environmental economics: individual incentives and public choices. MacMillan, Basingstoke. http://dx.doi.org/10.1007/978-1-349-24172-9

Oh, C., \& Svendsen, G. T. (2015). Command-And-Control or Taxation? The Cases of Water Regulation in California and Denmark. Environmental Management and Sustainable Development, 4(2).

Olson, M. (1965). The logic of collective action. Cambridge: Harvard University Press.

Speck, S., Nordic Council of Ministers, Nordic Council. (2006). The use of economic instruments in Nordic and Baltic environmental policy 2001-2005. Copenhagen: Nordic Council of Ministers.

Stavins, R. N. (2003). Market-based environmental policies: What can we learn from US experience (and related research)? Washington D.C.: Resources for the Future.

Stavins, R., \& Whitehead, B. (1997). Market-Based Environmental Policies. In M. R. Chertow, \& D. C. Etsy (Eds.), Thinking Ecologically. The Next Generation of Environmental Policy (pp. 105-113). Yale: Yale University Press, Yale University.

Svendsen, Gunnar L. H., \& Svendsen, G. T. (2004). The Creation and Destruction of Social Capital: Entrepreneurship, Co-operative Movements and Institutions. Edward Elgar Publishing, UK.

Tietenberg, T. (1990). Economic Instruments for Environmental Regulation. Oxford Review of Economic Policy, 6(1), 17-16.

Tietenberg, T. (2007). Water. In T. Tietenberg, \& L. Lewis (Eds.), Environmental Economics and Policy (pp. 162-184). Prentice Hall, US.

Zetland, D. (2009). The end of abundance: How water bureaucrats created and destroyed the southern California oasis. Water Alternatives, 2(3), 350-369.

\section{Copyright Disclaimer}

Copyright for this article is retained by the author(s), with first publication rights granted to the journal.

This is an open-access article distributed under the terms and conditions of the Creative Commons Attribution license (http://creativecommons.org/licenses/by/3.0/). 